\title{
The Birth Control Debate: 1930s-1940s
}

\author{
Shannon Mattice ${ }^{1}$
}

Throughout the 1930s and 1940s birth control became a part of a larger social problem that spanned across political and religious lines. Due to economic issues caused by the Great Depression, bringing children into the world was no longer a feasible dream for many families that already struggled with providing for themselves and any children they already had. The Comstock Laws prevented women from seeking out contraceptive methods to prevent unwanted pregnancies. Men, however, were encouraged during World War II to use contraceptives to prevent pregnancies. While white women were not being given choices on their own reproductive rights, women of color in the South were being forced into sterilization programs. These programs highlight the authority men had over women's agency at the time. The role of the church at the time is also explored as the Protestant and the Catholic church had drastically different views on the use of birth control. [Article copies available for a fee from The Transformative Studies Institute. E-mail address: journal@transformativestudies.org Website: http://www.transformativestudies.org 02021 by The Transformative Studies Institute. All rights reserved.]

KEYWODS: Birth Control, Great Depression, Sterilization, Agency, Protestant, Catholic.

\footnotetext{
${ }^{1}$ Shannon Mattice is a graduate student earning her Masters in History at the University at Buffalo. In May of 2019, she graduated summa cum laude from SUNY Potsdam with a BA in History and a minor in Women's Studies. Along with earning an advanced Honors degree, Shannon also graduated as a Presidential Scholar. While at SUNY Potsdam Shannon was the President of the History Association and in the spring of 2019 was awarded one of the Departmental Scholars Award from the History Department. In the spring of 2019, she also won the Provost's Award for Student Excellency in Research for her Presidential Scholars project. She presented this paper at the 2019 Gender, Sex and Sexuality Conference; she also presented her Presidential Scholars research at the SUNY Potsdam Learning and Research Fair and at the SUNY Undergrad Research Conference at SUNY Adirondack in April of 2019. Shannon is also a member of Phi Alpha Theta, the national history honors society. Address correspondence to: Shannon Mattice, e-mail: smattice@buffalo.edu.
} 